\title{
Osteogenic Differentiation of Human Adipose Tissue-Derived MSCs by Non-Toxic Calcium Poly(ethylene phosphate)s
}

\author{
Ilya Nifant'ev ${ }^{1,2, *(\mathbb{D})}$, Tatiana Bukharova ${ }^{3}{ }^{(\mathbb{D}}$, Alexander Dyakonov ${ }^{3}$, Dmitry Goldshtein ${ }^{3}$, \\ Elena Galitsyna ${ }^{3}$, Maxim Kosarev ${ }^{1}$, Andrey Shlyakhtin ${ }^{1}$, Dmitry Gavrilov ${ }^{1}$ \\ and Pavel Ivchenko ${ }^{1,2}$ (iD) \\ 1 Chemistry Department, M.V. Lomonosov Moscow State University, 1-3 Leninskie Gory, \\ 119991 Moscow, Russia; komrad.kosarev.maksim@gmail.com (M.K.); shlyahtinav@mail.ru (A.S.); \\ gavrosdm@gmail.com (D.G.); phpasha1@yandex.ru (P.I.) \\ 2 A.V. Topchiev Institute of Petrochemical Synthesis RAS, 29 Leninsky Pr., 119991 Moscow, Russia \\ 3 Research Centre for Medical Genetics, 1 Moskvorechye Str., 115522 Moscow, Russia; \\ bukharova-rmt@yandex.ru (T.B.); elemental190@gmail.com (A.D.); dv@rm7.ru (D.G.); \\ snowbars888@yandex.ru (E.G.) \\ * Correspondence: ilnif@yahoo.com or inif@org.chem.msu.ru; Tel.: +7-495-939-4098
}

Received: 31 October 2019; Accepted: 8 December 2019; Published: 11 December 2019

\begin{abstract}
There is a current clinical need for the development of bone void fillers and bioactive bone graft substitutes. The use of mesenchymal stem cells (MSCs) that are seeded into 3D scaffolds and induce bone generation in the event of MSCs osteogenic differentiation is highly promising. Since calcium ions and phosphates promote the osteogenic differentiation of MSCs, the use of the calcium complexes of phosphate-containing polymers is highly prospective in the development of osteogenic scaffolds. Calcium poly(ethylene phosphate)s (PEP-Ca) appear to be potentially suitable candidates primarily because of PEP's biodegradability. In a series of experiments with human adipose-tissue-derived multipotent mesenchymal stem cells (ADSCs), we demonstrated that PEP-Ca are non-toxic and give rise to osteogenesis gene marker, bone morphogenetic protein $2(B M P-2)$ and mineralization of the intercellular matrix. Owing to the synthetic availability of poly(ethylene phosphoric acid) block copolymers, these results hold out the possibility for the development of promising new polymer composites for orthopaedic and maxillofacial surgery.
\end{abstract}

Keywords: ring-opening polymerization; polyphosphates; calcium; stem cells; osteoinductivity; osteogenic differentiation; tert-butyl ethylene phosphate; phosphoric acid

\section{Introduction}

Every year, millions of surgical procedures involving bone excision, bone grafting and fracture repair are performed worldwide [1]. The rate of repair after these procedures is dependent on bone defect size and patient age. The lack of the healing capacity of osteogenic tissue results in the prepotency of the fibrous connective tissue, which is de facto a clinical failure [2]. Methods of tissue engineering reflect new insights in chemistry, biology and medicine. These methods aim to construct biological substitutes that can restore and maintain normal function in injured and diseased bone [3].

One of the most promising approaches involves the use of mesenchymal stem cells (MSCs) that are seeded into 3D scaffolds and induce bone generation by osteoinductive cues [1,4-7]. The design of such 3D scaffolds as a bone void filler can be implemented at the interface of organic chemistry, polymer chemistry, material science and cell biology by the development of the composites containing biodegradable synthetic polymers and calcium phosphates [8-11]. This approach seems to be prospective due to the variability of 
polymer characteristics [12-15] and osteoinductivity of calcium and phosphate ions [16,17]. However, this kind of composite shares some of the challenges arising from the incompatibility of organic polymers with calcium phosphates, therefore resulting in unpredictability of the composite's behaviour during regeneration against the backdrop of polymer degradation.

A whole new approach involves the use of synthetic polymers containing phosphate fragments able to chemically bond with calcium ions. Such polymers can be prepared by radical copolymerization involving phosphate-substituted vinyl monomers (Scheme 1a, polymer Type 1) $[18,19]$. However, in the strict sense, these polymers are not biodegradable. The second type of these prospective polymers can be prepared by the ring-opening polymerization (ROP) of cyclic ethylene phosphate monomers [20-24] followed by the transformation of poly(ethylene phosphate)s to poly(ethylene phosphoric acid)s (PEPA) or their salts [25-31] (Scheme 1b). The mild thermolysis of the polymers of tert-butyl ethylene phosphate $\left({ }^{t} \mathrm{BuOEP}\right)$ was found to be a simple and efficient method of PEPA preparation (Scheme 1c) [32,33].
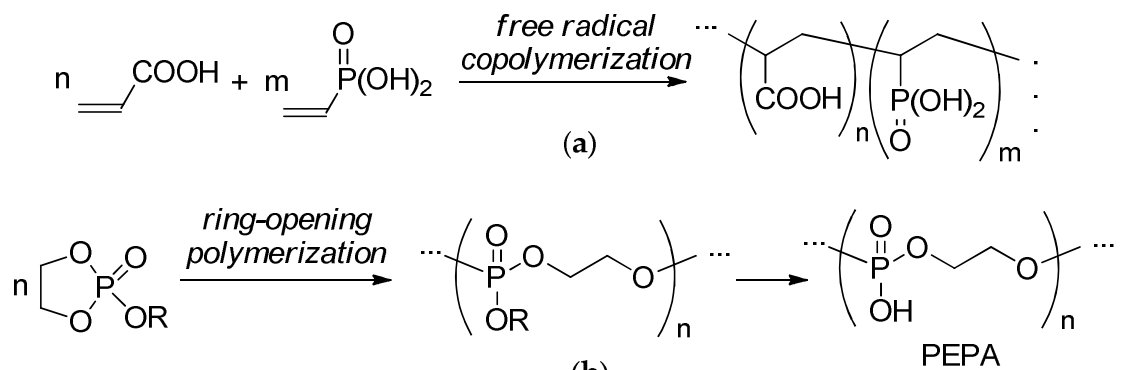

(b)

PEPA

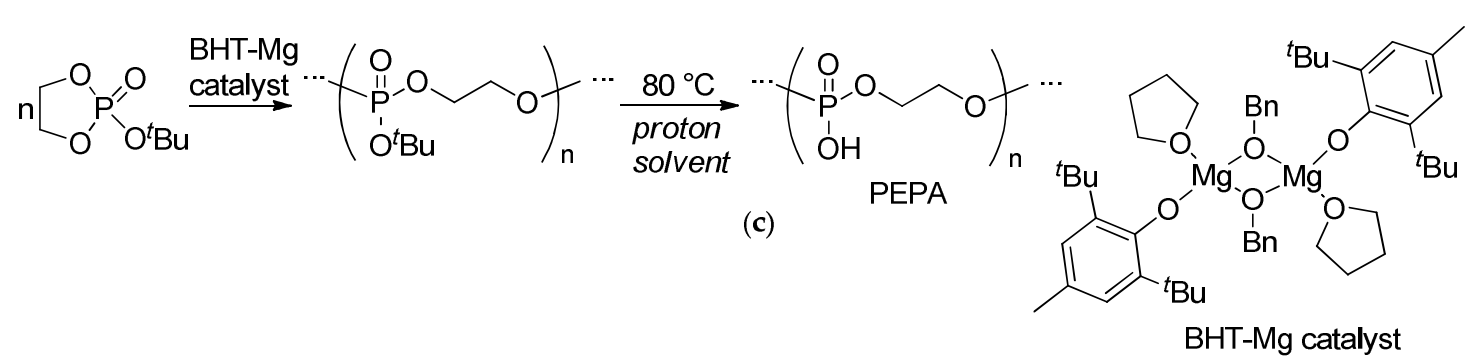

Scheme 1. Phosphate-containing polymers: (a) Type 1, the products of the radical (co)polymerization of vinyl phosphates; (b) Type 2, poly(ethylene phosphoric acid) (PEPA) obtained by ring-opening polymerization (ROP) of cyclic ethylene phosphates followed by hydrolysis; (c) Efficient method of PEPA preparation by mild thermolysis of the polymers obtained by the ROP of tert-butyl ethylene phosphate $\left({ }^{t} \mathrm{BuOEP}\right)[33]$.

As previously demonstrated [34], the complexes of poly(vinyl phosphate)s with calcium ions show an osteoinductive effect that promotes human bone-marrow-derived MSCs. Despite the obvious promise of poly(ethylene phosphate)s and PEPA for biomedical applications [20-22,30,35-44], the key properties of PEPA calcium complexes-namely, toxicity and ability to provoke MSCs osteogenic differentiation-have not been investigated. In the present communication, we report that such PEPA complexes are non-toxic and give rise to osteogenesis gene marker bone morphogenetic protein $2(B M P-2)$ and mineralization of the intercellular matrix in experiments with human adipose-tissue-derived multipotent MSCs (ADSCs).

\section{Results and Discussion}

\subsection{Preparation of PEPA and PEPA Salts}

The sample of poly $\left({ }^{t} \mathrm{BuOEP}\right)$ was prepared by the ROP of ${ }^{t} \mathrm{BuOEP}$ in the presence of a heteroleptic complex $[(\mathrm{BHT}) \mathrm{Mg}(\mu-\mathrm{OBn})(\mathrm{THF})]_{2}$ as shown in Scheme 1c (see Section 3.1 for details). The composition 
of the polymer was established by end-group analysis of the ${ }^{1} \mathrm{H}$ NMR spectrum as $\mathrm{BnO}\left({ }^{t} \mathrm{BuOEP}\right)_{43} \mathrm{H}$ $\left(M_{n}=7.85 \times 10^{3}\right.$, see Figure S1 in the Supporting Information). This composition was in good agreement with SEC data $\left(M_{n}=7.91 \times 10^{3}, \oplus_{M}=1.24\right)$. DSC and TGA demonstrated that poly $\left({ }^{t} \mathrm{BuOEP}\right)$ decomposed at $105-110{ }^{\circ} \mathrm{C}$ in bulk [33]. The constant weight of the polymer sample was reached after $6 \mathrm{~h}$ of drying at $50^{\circ} \mathrm{C}$ and 0.01 Torr.

The solution of PEPA containing the mixture of $\mathrm{BnO}(\mathrm{HOEP}){ }_{43} \mathrm{H}$ and $\mathrm{HO}(\mathrm{HOEP}){ }_{43} \mathrm{H}$ was obtained by heating the aqueous dispersion of $\mathrm{BnO}\left({ }^{t} \mathrm{BuOEP}\right){ }_{43} \mathrm{H}$ for 40 min at $80^{\circ} \mathrm{C}$. The molar concentration of phosphate groups in the PEPA solution was determined by ${ }^{31} \mathrm{P}$ NMR spectroscopy using trimethyl phosphate as an internal standard (see Section 3.1 for details).

Aqueous PEPA solution with a concentration of phosphate groups of $0.443 \mathrm{mmol} / \mathrm{g}$ was used for the preparation of sodium and calcium salts by the reactions with calculated amounts of $\mathrm{NaHCO}_{3}$ and $\mathrm{CaCO}_{3}$ in phosphate/metal molar ratios of 1:1 (Na-PEP, Ca1-PEP) and 2:1 (Ca2-PEP) (see Section 3.1 for details).

\subsection{The Influence of PEPA Salts on ADSCs' Adhesion and Proliferation}

The analysis of cell adhesion demonstrated that Ca2-PEP substantially contributed to the adhesion of ADSCs (see Section 3.3 and Figure S15 in the Supporting Information for details). At the same time, the effect of cell proliferation was insignificantly affected by the solutions of PEPA salts (Figure 1). The major finding from the evaluation of the experimental results was the absence of the toxic effect of PEPA salts. This result is essential for the prospects of biomedical applications of PEPA-containing polymers.

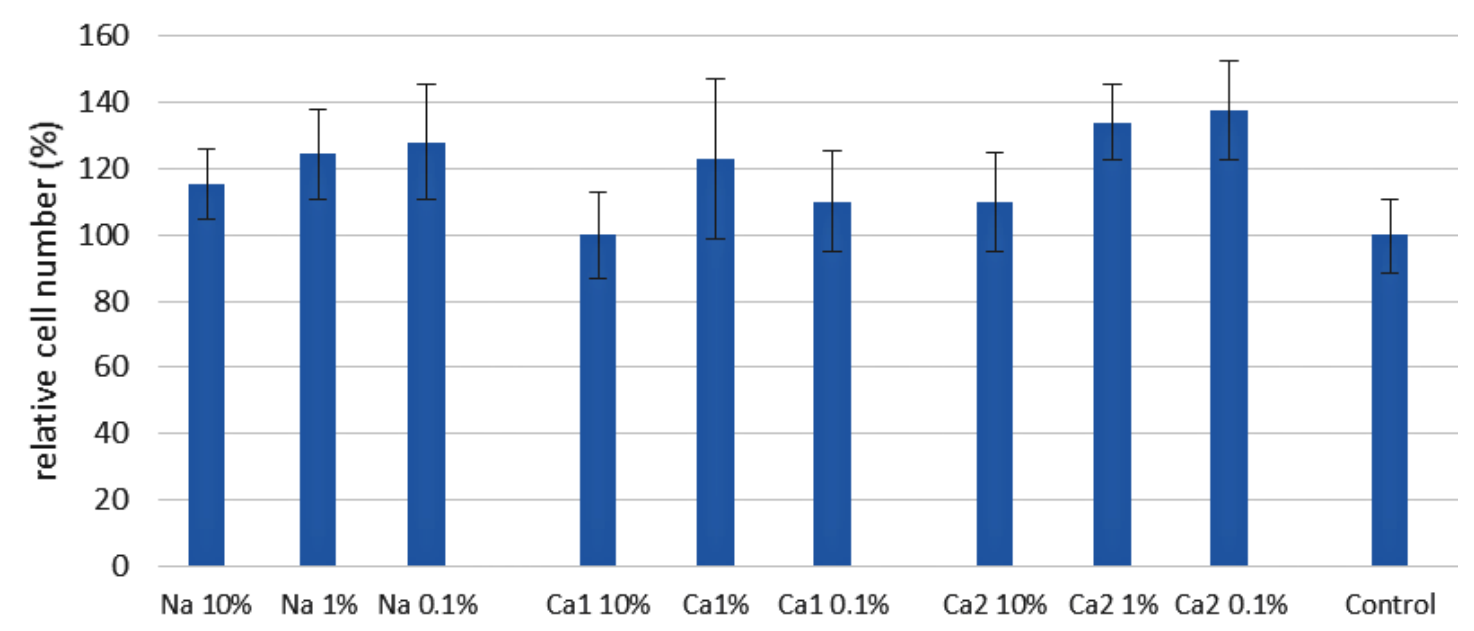

Figure 1. The results of 7-day cell adhesion and proliferation experiments for the solutions of PEPA metal salts diluted by the factors of 1000,100 and 10. The starting solutions of the salts were prepared in phosphate/metal molar ratios of 1:1 (Na-PEP, Ca1-PEP) and 2:1 (Ca2-PEP). The initial concentration of phosphate groups was $0.443 \mathrm{mmol} / \mathrm{g}$. The percentage of the cell viability relative to control (additive-free plates) is presented.

\subsection{Osteogenic Potential of the PEPA Salts}

To examine the effect of PEPA salts on osteogenic induction, ADSCs were cultured in media with PEPA salts of different concentrations ranging from $0.1 \%$ to $10 \%$. The results of osteogenic differentiation were determined by the expression level of the BMP-2 gene using RT-PCR analysis and by mineralization assay with alizarin red $S$ staining (see Section 3.4 for details).

Our results demonstrated that calcium salts Ca1-PEP and Ca2-PEP at a concentration of $10 \%$ significantly increased the expression of the BMP-2 gene at 7 and 14 days. The osteogenic effect of PEPA calcium salts was higher than of $\beta$-glycerophosphate (Figure 2). We also found significant 
mineralization of the extracellular matrix during the cultivation of ADSCs with Ca1-PEP and Ca2-PEP at a concentration of $10 \%$ (Figure 3). Na-PEP did not affect differentiation of ADSCs.
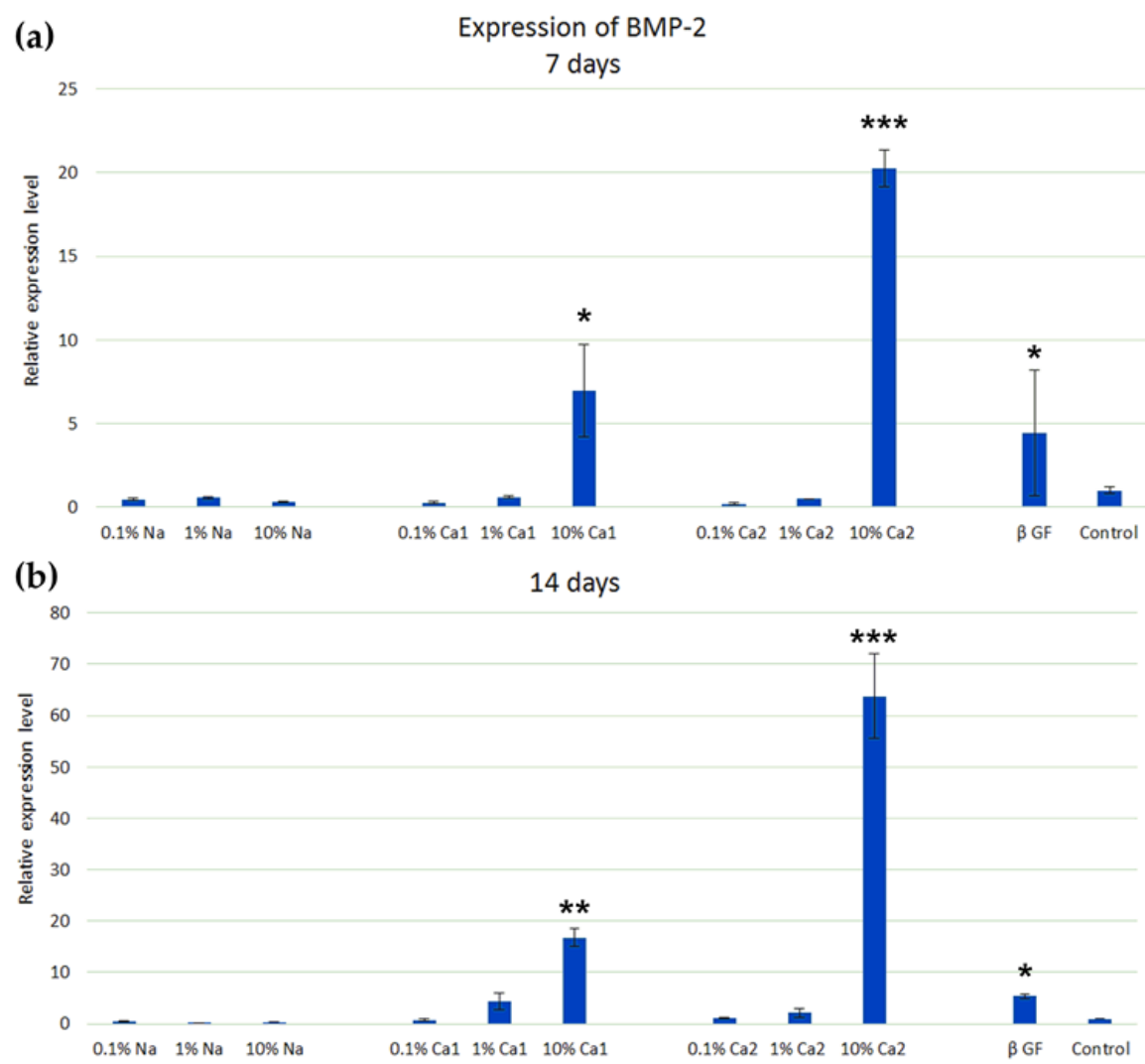

Figure 2. Differentiation of adipose-tissue-derived multipotent mesenchymal stem cells (ADSCs) with the solutions of PEPA salts Na-PEP, Ca1-PEP and Ca2-PEP of different concentrations in the presence of $\beta$-glycerophosphate and in the control experiment in the absence of additives. The expression of the $B M P$-2 gene in ADSCs on days 7 (a) and $14(\mathbf{b})$. RT-PCR analysis. Statistical difference between a test group and control $\left({ }^{*} p<0.05,{ }^{* *} p<0.01,{ }^{* * *} p<0.001\right)$.

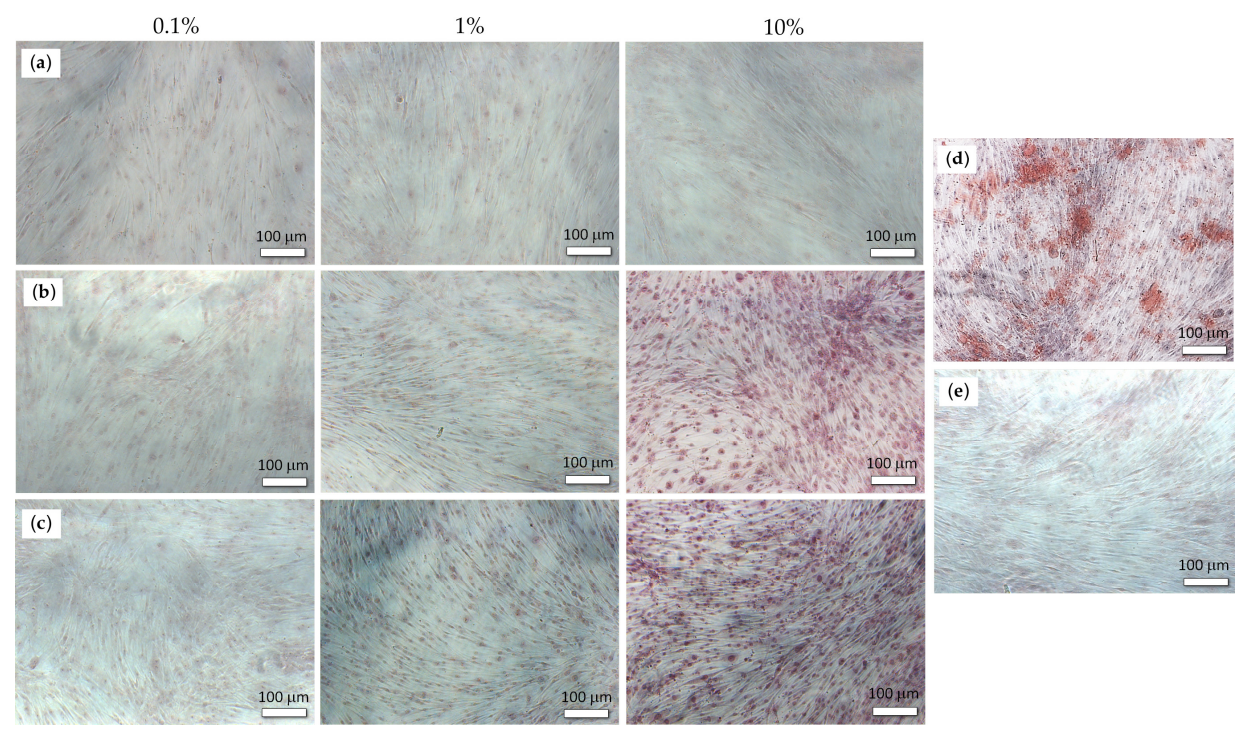

Figure 3. The mineralization of the extracellular matrix of ADSCs on day 14 in the presence of Na-PEP (a), Ca1-PEP (b), Ca2-PEP (c), $\beta$-glycerophosphate (d) and control experiment in the absence of additives (e). The level of Alizarin red $S$ staining. 


\section{Materials and Methods}

\subsection{Synthesis of PEPA and Metal Salts}

\subsubsection{General Experimental Remarks}

All the synthetic and polymerization experiments were conducted under an argon atmosphere. Tetrahydrofuran (THF), diethyl ether $\left(\mathrm{Et}_{2} \mathrm{O}\right)$ and triethylamine were refluxed with $\mathrm{Na} /$ benzophenone/ dibenzo-18-crown-6 and distilled prior to use. Pentane was refluxed for $10 \mathrm{~h}$ over sodium and then distilled and stored under an argon atmosphere over sodium. 2,6-Di-tert-butyl-4- methylphenol (BHT, $\geq 99 \%$, Merck, NJ, USA), di-n-butylmagnesium (1.0 M solution in heptane, Merck, NJ, USA) and acetic acid ( $\geq 99.9 \%$, Acros Organics, Geel, Belgium) were used as purchased. Benzyl alcohol (BnOH, 99\%, Acros Organics, Geel, Belgium) and tert-butyl alcohol ( ${ }^{t} \mathrm{BuOH}, 99 \%$, Merck, NJ, USA) were distilled over $\mathrm{BaO}$ and stored under argon. 2-Chloro-2-oxo-1,3,2-dioxaphospholane [45], 2-tert-butoxy-2-oxo-1,3,2-dioxaphospholane ${ }^{t} \mathrm{BuOEP}[23]$, and BHT-Mg catalyst $[(\mathrm{BHT}) \mathrm{Mg}(\mu-\mathrm{OBn})(\mathrm{THF})]_{2}[46]$ were prepared according to previously described methods (for details, see Section S1 in the Supporting Information).

\subsubsection{Synthesis of Poly $\left({ }^{\mathrm{t}} \mathrm{BuOEP}\right)$}

The solution of the catalyst $[(\mathrm{BHT}) \mathrm{Mg}(\mu-\mathrm{OBn})(\mathrm{THF})]_{2}(125 \mathrm{mg}, 0.296 \mathrm{mmol})$ in $\mathrm{CH}_{2} \mathrm{Cl}_{2}(4.1 \mathrm{~mL})$ was introduced to the vial containing ${ }^{t} \mathrm{BuOEP}(2.058 \mathrm{~g}, 11.424 \mathrm{mmol})$ at $20{ }^{\circ} \mathrm{C}$. After $70 \mathrm{~h}$, the polymer was precipitated from the reaction mixture by the addition of pentane $(25 \mathrm{~mL})$. The polymer was separated, dissolved in $5 \mathrm{~mL}$ of $\mathrm{CH}_{2} \mathrm{Cl}_{2}$ and passed through a $0.45 \mu \mathrm{m}$ PTFE membrane filter using a syringe. The solvents were removed under reduced pressure, and the residue was dried at $50{ }^{\circ} \mathrm{C}$ and 0.01 Torr to constant weight. The yield was $1.64 \mathrm{~g}(80 \%)$ of pale-yellow sticky solid, $M_{n}=7.91 \times 10^{3}$, $\bigoplus_{M}=1.24$ (SEC). For ${ }^{1} \mathrm{H}$ and ${ }^{31} \mathrm{P}$ NMR spectra of the polymer obtained, see Figures S9 and S10 in the Supporting Information.

\subsubsection{Preparation of the PEPA Solution}

Poly $\left({ }^{t} \mathrm{BuOEP}\right)(15,729 \mathrm{~g})$ was dispersed in distilled water $(14.3 \mathrm{~g})$. The emulsion was heated with stirring at $80{ }^{\circ} \mathrm{C}$ for $40 \mathrm{~min}$. After heating, the solution was washed by $\mathrm{CH}_{2} \mathrm{Cl}_{2}(4 \times 10 \mathrm{~mL})$, heated to $60{ }^{\circ} \mathrm{C}$ for $\mathrm{CH}_{2} \mathrm{Cl}_{2}$ removal, degassed under vacuum, and passed through a $0.45 \mu \mathrm{m}$ PTFE membrane filter. The filter was washed by a minimal volume of water. As a result, $19.7 \mathrm{~g}$ of PEPA solution was obtained. The molar concentration of phosphate groups in PEPA solution was determined as $0.443 \mathrm{M}$ by ${ }^{31} \mathrm{P}$ NMR spectroscopy using trimethyl phosphate as an internal standard (see Figure S13 in the Supporting Information).

\subsubsection{Preparation of the Solutions of PEPA Metal Salts}

Na-PEP. $\mathrm{NaHCO}_{3}(223 \mathrm{mg}, 2.66 \mathrm{mmol})$ was added to PEPA stock solution $(6 \mathrm{~g}, 2.66 \mathrm{mmol}$ of $\mathrm{P}(\mathrm{O}) \mathrm{OH}$ groups). After the cessation of $\mathrm{CO}_{2}$ evaluation, the solution was passed through a $0.45 \mu \mathrm{m}$ PTFE membrane filter. Ca1-PEP and Ca2-PEP were obtained in a similar way by the reactions of $\mathrm{CaCO}_{3}(266 \mathrm{mg} / 2.66 \mathrm{mmol}$ or $133 \mathrm{mg} / 1.33 \mathrm{mmol}$, respectively) with PEPA (6 g, $2.66 \mathrm{mmol}$ of $\mathrm{P}(\mathrm{O}) \mathrm{OH}$ groups).

\subsection{Cultivation of the ADSCs}

Based on the data compiled and reported earlier [47-49], human adipose-tissue-derived stem cells (ADSCs) were isolated from lipoaspirate obtained by liposuction after approval from the Research Centre for Medical Genetics (RCMG) Ethics Committee (The permit to use the cell cultures in research was granted by Bioethics Committee of the RCMG, Record No. 6/5, approved on 15 November 2016). ADSC was cultured in Dulbecco's Modified Eagle Medium F-12 (DMEM-F12) (PanEco, Moscow, Russian Federation) containing 10\% foetal bovine serum (FBS; PAA Laboratories, Linz, Austria), $4 \mathrm{mM}$ L-glutamine (PanEco, Moscow, Russian Federation) and $0.1 \mathrm{mg} / \mathrm{mL}$ amikacin (Joint-Stock 
Company Kurgan Medicines and Products Sintez, Kurgan, Russian Federation) at $37^{\circ} \mathrm{C}$ in a $5 \% \mathrm{CO}_{2}$ humidified atmosphere.

\subsection{The Study of the Influence of PEPA Salts on Cell Adhesion and Proliferation}

For the study of the influence of PEPA salts on cell adhesion and proliferation, PEPA salts with a concentration of $0.443 \mathrm{mmol} / \mathrm{g}$ were dissolved in a physiological solution (PanEco, Moscow, Russian Federation) to concentrations of $0.1 \%, 1 \%$ and $10 \%$. PEPA salt solutions were applied to the wells of a 48 -well $300 \mu \mathrm{L}$ culture plate for $2 \mathrm{~h}$ at $37^{\circ} \mathrm{C}$ in order to adsorb PEPA salt onto the plates. Then, unbound PEPA salt was removed. Control plates were salt free.

ADSC cells were seeded to the surface of the PEPA-adsorbed 48-well culture plates at a density of $2.0 \times 10^{4}$ cells/well and cultured in growth medium at $37^{\circ} \mathrm{C}$ in a $5 \% \mathrm{CO}_{2}$ humidified atmosphere. The number of cells were counted in six to ten randomly selected fields in each well after one and seven days. To visualize each individual cell, the nuclei were stained with 4',6-diamidino-2-phenylindole (DAPI) (Sigma-Aldrich, St. Louis, MO, USA), $1 \mu \mathrm{g} / \mathrm{mL}$ in PBS (see Figure S14 in the Supporting Information).

\subsection{The Study of the Osteogenic Potential of PEPA Salts}

For osteogenic differentiation, ADSCs were cultured in 48-well culture plates at a density of $2.0 \times 10^{4}$ cells per well in Dulbecco's Modified Eagle Medium (DMEM) (PanEco, Moscow, Russian Federation) containing 10\% FBS (PAA Laboratories, Linz, Austria), 50 mg/L L-ascorbic acid (Sigma-Aldrich, St. Louis, USA), 4 mM L-glutamine (PanEco, Moscow, Russian Federation), $0.1 \mathrm{mg} / \mathrm{mL}$ amikacin (Joint-Stock Company Kurgan Medicines and Products Sintez, Kurgan, Russian Federation) and PEPA salts at concentrations of $0.1 \%, 1 \%$ and $10 \%$ or $10 \mathrm{mM} / \mathrm{L} \beta$-glycerophosphate (Sigma-Aldrich, St. Louis, MO, USA) at $37^{\circ} \mathrm{C}$ in a $5 \% \mathrm{CO}_{2}$ humidified atmosphere.

In vitro mineralization was analysed 14 days after osteogenic differentiation. The ADSCs were fixed in 70\% ethanol (Ferain, Moscow, Russian Federation) for $30 \mathrm{~min}$ and stained with $40 \mathrm{mM}$ Alizarin Red S (pH 4.12, PanEco, Moscow, Russian Federation) for $10 \mathrm{~min}$. The plates were washed with distilled water and analysed with an Axio Observer.D1 microscope equipped with AxioCam HRc (Carl Zeiss Ltd., Cambridge, United Kingdom).

For gene expression analysis, total RNA was extracted from cells after differentiation using the RNeasy Mini Kit (QIAGEN, Hilden, Germany) according to the manufacturer's instructions. cDNA was synthesized using the RevertAid ${ }^{\mathrm{TM}}$ First Strand cDNA Synthesis Kit (Thermo Fisher Scientific, Waltham, MS, USA) using reverse transcriptase M-MuLV and oligo-dT primers. A quantitative real-time polymerase chain reaction (RT-PCR) was run in a CFX-96 (Bio-Rad Laboratories, Hercules, CA, USA) PCR thermal cycler three times for each sample using $5 \times$ qPCRmix-HSSYBR (Evrogen, Moscow, Russian Federation) and specific primers for osteoblast-related BMP-2: forward 5'-ACTACCAGAAACGAGTGGGAA-3', reverse 5'-GCATCTGTTCTCGGAAAACCT-3' and glyceraldehyde-3-phosphate dehydrogenase (GAPDH): forward 5'-GAAGGTGAAGGTCGGAGTACA-3' and reverse 5'-TTCACACCCATGACGAGACAT-3. The RT-PCR was performed as following: denaturation at $95^{\circ} \mathrm{C}$ for 6 min followed by 45 cycles of denaturation at $95{ }^{\circ} \mathrm{C}$ for $10 \mathrm{~s}$, annealing at $55.6-62.3^{\circ} \mathrm{C}$ for $15 \mathrm{~s}$, then elongation at $72{ }^{\circ} \mathrm{C}$ for $20 \mathrm{~s}$. The specificity of real-time PCR was verified by melting curve analysis $\left(70-98^{\circ} \mathrm{C}\right.$, with a $0.5^{\circ} \mathrm{C}$ increment each cycle). The obtained results of the BMP-2 expression were normalized by GAPDH expression in the same sample. The relative expression of genes of interest was calculated by the $2^{-\Delta \Delta C t}$ method.

\subsection{Statistical Analysis}

One-way ANOVA followed by Dunnett's multiple comparisons test was performed using GraphPad Prism version 7.00 for Windows (GraphPad Software, La Jolla, CA, USA). The values reported are the average \pm standard deviations. Values of $p<0.05$ were considered statistically significant. 


\section{Conclusions}

We prepared sodium and calcium salts of poly(ethylene phosphoric acid) (PEPA) and studied the influence of these salts on the growth and differentiation of human adipose tissue-derived stem cells (ADSCs). We found that neither sodium nor calcium PEPA salts demonstrated a toxic effect in 7-day experiments. Furthermore, calcium PEPA salts clearly induced osteogenic differentiation of ADSCs, whereas sodium salts were inactive, within the margin of experimental error. In considering the possibility of the synthesis of polyester-PEPA block copolymers, we can develop next-generation polymer scaffolds for tissue engineering with regards to orthopaedic and maxillofacial surgery.

Supplementary Materials: Supplementary materials can be found at http://www.mdpi.com/1422-0067/20/24/6242/ s1. Detailed description of the synthesis of ${ }^{t} \mathrm{BuOEP}$ and BHT-Mg catalyst. NMR spectra of ethylene phosphite and ethylene phosphates (Figures S1-S7), $[(\mathrm{BHT}) \mathrm{Mg}(\mu-\mathrm{OBn})(\mathrm{THF})]_{2}$ (Figure S8), poly $\left({ }^{\mathrm{t} B u O E P}\right)$ (Figures S9 and S10) and PEPA (Figures S11-S13). Figure S14, The microphotograph of DAPI-coloured cells; Figure S15, The results of cell adhesion and proliferation experiments for the solutions of PEPA metal salts (Na, Ca1 and Ca2) diluted by the factors of 1000, 100 and 10. The numbers of cells in the field of view are presented in blue (after 1 day) and in red (after 7 days).

Author Contributions: Conceptualization, I.N.; methodology, I.N. and D.G. (Dmitry Goldshtein).; data curation, E.G.; validation, I.N., T.B. and A.D.; formal analysis, T.B. and A.D.; investigation, T.B., A.D., E.G., M.K., A.S. and D.G. (Dmitry Gavrilov); Writing-Original draft preparation, T.B. and P.I.; Writing-Review and editing, I.N. and P.I.; visualization, P.I.; supervision, I.N. and D.G. (Dmitry Goldshtein); project administration, I.N.; funding acquisition, I.N.

Funding: This research was funded by the Russian Science Foundation, grant number 16-13-10344, and was carried out within the State Program of TIPS RAS (as part of polymerization experiments and polymer analysis).

Acknowledgments: The authors are grateful for the use of the equipment of the TIPS RAS Center of Collective Use: "New petrochemical processes, polymer composites and adhesives".

Conflicts of Interest: The authors declare no conflicts of interest.

\section{Abbreviations}

$\begin{array}{ll}\text { ADSCs } & \text { human adipose-tissue-derived stem cells } \\ \text { BHT } & \text { 2,6-di-tert-butyl-4-methylphenol } \\ \text { BMP-2 } & \text { bone morphogenetic protein 2 } \\ \text { DSC } & \text { differential scanning calorimetry } \\ \text { GAPDH } & \text { glyceraldehyde-3-phosphate dehydrogenase } \\ \text { MSCs } & \text { mesenchymal stem cells } \\ \text { PEP } & \text { poly(ethylene phosphate) } \\ \text { PEPA } & \text { poly(ethylene phosphoric acid) } \\ \text { PTFE } & \text { poly(tetrafluoroethylene) } \\ \text { RCMG } & \text { Research Centre of Medical Genetics } \\ \text { ROP } & \text { ring-opening polymerization } \\ \text { TGA } & \text { thermogravimetric analysis }\end{array}$

\section{References}

1. Yousefi, A.-M.; James, P.F.; Akbarzadeh, R.; Subramanian, A.; Flavin, C.; Oudadesse, H. Prospect of Stem Cells in Bone Tissue Engineering: A Review. Stem Cells Int. 2016, 2016, 6180487. [CrossRef]

2. Liu, Y.; Wu, G.; de Groot, K. Biomimetic coatings for bone tissue engineering of critical-sized defects. J. R. Soc. Interface 2010, 7, S631-S647. [CrossRef]

3. Hutmacher, D.W. Scaffolds in tissue engineering bone and cartilage. Biomaterials 2000, 21, $2529-2543$. [CrossRef]

4. Patel, D.M.; Shah, J.; Srivastava, A.S. Therapeutic Potential of Mesenchymal Stem Cells in Regenerative Medicine. Stem Cells Int. 2013, 2013, 496218. [CrossRef]

5. Oryan, A.; Kamali, A.; Moshiri, A.; Eslaminejad, M.B. Role of Mesenchymal Stem Cells in Bone Regenerative Medicine: What Is the Evidence? Cells Tissues Organs 2017, 204, 59-83. [CrossRef] 
6. Ansari, A.S.; Yazid, M.D.; Sainik, N.Q.A.V.; Razali, R.A.; Saim, A.B.; Idrus, R.B.H. Osteogenic Induction of Wharton's Jelly-Derived Mesenchymal Stem Cell for Bone Regeneration: A Systematic Review. Stem Cells Int. 2018, 2018, 2406462. [CrossRef]

7. Humbert, P.; Brennan, M.Á.; Davison, N.; Rosset, P.; Trichet, V.; Blanchard, F.; Layrolle, P. Immune Modulation by Transplanted Calcium Phosphate Biomaterials and Human Mesenchymal Stromal Cells in Bone Regeneration. Front. Immunol. 2019, 10, 663. [CrossRef]

8. Liang, X.; Duan, P.; Gao, J.; Guo, R.; Qu, Z.; Li, X.; He, Y.; Yao, H.; Ding, J. Bilayered PLGA/PLGA-HAp Composite Scaffold for Osteochondral Tissue Engineering and Tissue Regeneration. ACS Biomater. Sci. Eng. 2018, 4, 3506-3521. [CrossRef]

9. Kunisch, E.; Gunnella, F.; Wagner, S.; Dees, F.; Maenz, S.; Bossert, J.; Jandt, K.D.; Kinne, R.W. The poly (l-lactid-co-glycolide; PLGA) fiber component of brushiteforming calcium phosphate cement induces the osteogenic differentiation of human adipose tissue-derived stem cells. Biomed. Mater. 2019, 14, 055012. [CrossRef]

10. Wang, Z.; Liang, R.; Jiang, X.; Xie, J.; Cai, P.; Chen, H.; Zhan, X.; Lei, D.; Zhao, J.; Zheng, L. Electrospun PLGA/PCL/OCP nanofiber membranes promote osteogenic differentiation of mesenchymal stem cells (MSCs). Mater. Sci. Eng. C 2019, 104, 109796. [CrossRef]

11. Hasan, A.; Byambaa, B.; Morshed, M.; Cheikh, M.I.; Shakoor, R.A.; Mustafy, T.; Marei, H.E. Advances in osteobiologic materials for bone substitutes. Tissue Eng. Regen. Med. 2018, 12, 1448-1468. [CrossRef]

12. Naira, L.S.; Laurencin, C.T. Biodegradable polymers as biomaterials. Prog. Polym. Sci. 2007, 32, $762-798$. [CrossRef]

13. Vert, M. Aliphatic Polyesters: Great Degradable Polymers That Cannot Do Everything. Biomacromolecules 2005, 6, 538-546. [CrossRef]

14. Armentano, I.; Dottori, M.; Fortunati, E.; Mattioli, S.; Kenny, J.M. Biodegradable polymer matrix nanocomposites for tissue engineering: A review. Polym. Degrad. Stab. 2010, 95, 2126-2146. [CrossRef]

15. Farah, S.; Anderson, D.G.; Langer, R. Physical and mechanical properties of PLA, and their functions in widespread applications-A comprehensive review. Adv. Drug Deliv. Rev. 2016, 107, 367-392. [CrossRef]

16. Ghavimi, S.A.A.; Allen, B.N.; Stromsdorfer, J.L.; Kramer, J.S.; Li, X.; Ulery, B.D. Calcium and phosphate ions as simple signaling molecules with versatile osteoinductivity. Biomed. Mater. 2018, 13, 055005. [CrossRef]

17. Nakagawa, Y.; Muneta, T.; Tsuji, K.; Ichinose, S.; Hakamatsuka, Y.; Koga, H.; Sekiya, I. $\beta$-Tricalcium Phosphate Micron Particles Enhance Calcification of Human Mesenchymal Stem Cells In Vitro. J. Nanomater. 2013, 426786. [CrossRef]

18. Dey, R.E.; Zhong, X.; Youle, P.J.; Wang, Q.G.; Wimpenny, I.; Downes, S.; Hoyland, J.A.; Watts, D.C.; Gough, J.E.; Budd, P.M. Synthesis and Characterization of Poly(vinylphosphonic acid-co-acrylic acid) Copolymers for Application in Bone Tissue Scaffolds. Macromolecules 2016, 49, 2656-2662. [CrossRef]

19. Dey, R.E.; Wimpenny, I.; Gough, J.E.; Watts, D.C.; Budd, P.M. Poly(vinylphosphonic acid-co-acrylic acid) hydrogels: The effect of copolymer composition on osteoblast adhesion and proliferation. J. Biomed. Mater. Res. 2018, 106, 255-264. [CrossRef]

20. Steinbach, T.; Wurm, F.R. Poly(phosphoester)s: A new platform for degradable polymers. Angew. Chem. Int. Ed. 2015, 54, 6098-6108. [CrossRef]

21. Yilmaz, Z.E.; Jérôme, C. Polyphosphoesters: New trends in synthesis and drug delivery applications. Macromol. Biosci. 2016, 16, 1745-1761. [CrossRef]

22. Bauer, K.N.; Tee, H.T.; Velencoso, M.M.; Wurm, F.R. Main-chain poly(phosphoester)s: History, syntheses, degradation, bio-and flame-retardant applications. Prog. Polym. Sci. 2017, 73, 61-122. [CrossRef]

23. Nifant'ev, I.E.; Shlyakhtin, A.V.; Bagrov, V.V.; Komarov, P.D.; Kosarev, M.A.; Tavtorkin, A.N.; Minyaev, M.E.; Roznyatovsky, V.A.; Ivchenko, P.V. Controlled ring-opening polymerisation of cyclic phosphates, phosphonates and phosphoramidates catalysed by hereroleptic BHT-alkoxy magnesium complexes. Polym. Chem. 2017, 8 , 6806-6816. [CrossRef]

24. Nifant'ev, I.; Shlyakhtin, A.; Kosarev, M.; Karchevsky, S.; Ivchenko, P. Mechanistic Insights of BHT-Mg-Catalyzed Ethylene Phosphate's Coordination Ring-Opening Polymerization: DFT Modeling and Experimental Data. Polymers 2018, 10, 1105. [CrossRef]

25. Kaluzynski, K.; Libisowski, J.; Penczek, S. A New Class of Synthetic Polyelectrolytes. Acidic Polyesters of Phosphoric Acid (Poly(hydroxyalkylene phosphates)). Macromolecules 1976, 9, 365-367. [CrossRef] 
26. Penczek, S.; Biela, T.; Klosinski, P.; Lapienis, G. Polymerization of phosphorus containing cyclic monomers: Synthesis of polymers related to biopolymers. Makromol. Chem. Macromol. Symp. 1986, 6, 123-153. [CrossRef]

27. Wan, A.C.A.; Mao, H.-Q.; Wang, S.; Phua, S.H.; Lee, G.P.; Pan, J.; Lu, S.; Wang, J.; Leong, K.W. Poly(phosphoester) ionomers as tissue-engineering scaffolds. J. Biomed. Mater. Res. 2004, 70B, 91-102. [CrossRef]

28. Iwasaki, Y.; Kawakita, T.; Yusa, S. Thermoresponsive Polyphosphoesters Bearing Enzyme-cleavable Side Chains. Chem. Lett. 2009, 38, 1054-1055. [CrossRef]

29. Ergul Yilmaz, Z.; Debuigne, A.; Calvignac, B.; Boury, F.; Jerome, C. Double hydrophilic polyphosphoester containing copolymers as efficient templating agents for calcium carbonate microparticles. J. Mater. Chem. B 2015, 3, 7227-7236. [CrossRef]

30. Hirano, Y.; Iwasaki, Y. Bone-specific poly(ethylene sodium phosphate)-bearing biodegradable nanoparticles. Coll. Surf. B 2017, 153, 104-110. [CrossRef]

31. Otaka, A.; Iwasaki, Y. Endocytosis of poly(ethylene sodium phosphate) by macrophages and the effect of polymer length on cellular uptake. J. Ind. Eng. Chem. 2019, 75, 115-122. [CrossRef]

32. Yasuda, H.; Sumitani, M.; Nakamura, A. Novel Synthesis of Acidic Polyesters of Phosphoric Acid by Thermal Elimination of Isobutylene from Poly(alkylene tert-butyl phosphates). Macromolecules 1981, 14, 458-460. [CrossRef]

33. Nifant'ev, I.E.; Shlyakhtin, A.V.; Bagrov, V.V.; Komarov, P.D.; Tavtorkin, A.N.; Minyaev, M.E.; Kosarev, M.A.; Ivchenko, P.V. Synthesis in aqueous media of poly(ethylene phosphoric acids) by mild thermolysis of homopolymers and block copolymers based on tert-butyl ethylene phosphate. Eur. Polym. J. 2018, 106, 249-256. [CrossRef]

34. Wang, Q.G.; Wimpenny, I.; Dey, R.E.; Zhong, X.; Youle, P.J.; Downes, S.; Watts, D.C.; Budd, P.M.; Hoyland, J.A.; Gough, J.E. The unique calcium chelation property of poly(vinyl phosphonic acid-co-acrylic acid) and effects on osteogenesis in vitro. J. Biomed. Mater. Res. 2018, 106, 168-179. [CrossRef]

35. Penczek, S.; Pretula, J.; Kaluzynski, K. Poly(alkylene phosphates): From Synthetic Models of Biomacromolecules and Biomembranes toward Polymer-Inorganic Hybrids (Mimicking Biomineralization). Biomacromolecules 2005, 6, 547-551. [CrossRef]

36. Wang, D.A.; Williams, C.G.; Yang, F.; Cher, N.; Lee, H.; Elisseeff, J.H. Bioresponsive phosphoester hydrogels for bone tissue engineering. Tissue Eng. 2005, 11, 201-213. [CrossRef]

37. Du, J.-Z.; Du, X.-J.; Mao, C.-Q.; Wang, J. Tailor-made dual pH-sensitive polymer-doxorubicin nanoparticles for efficient anticancer drug delivery. J. Am. Chem. Soc. 2011, 133, 17560-17563. [CrossRef]

38. Wang, Y.-C.; Yuan, Y.-Y.; Du, J.-Z.; Yang, X.-Z.; Wang, J. Recent progress in polyphosphoesters: From controlled synthesis to biomedical applications. Macromol. Biosci. 2009, 9, 1154-1164. [CrossRef]

39. Zhai, X.; Huang, W.; Liu, J.; Pang, Y.; Zhu, X.; Zhou, Y.; Yan, D. Micelles from amphiphilic block copolyphosphates for drug delivery. Macromol. Biosci. 2011, 11, 1603-1610. [CrossRef]

40. Penczek, S.; Pretula, J.B.; Kaluzynski, K.; Lapienis, G. Polymers with Esters of Phosphoric Acid Units: From Synthesis, Models of Biopolymers to Polymer-Inorganic Hybrids. Isr. J. Chem. 2012, 52, 306-319. [CrossRef]

41. McKinlay, C.J.; Waymouth, R.M.; Wender, P.A. Cell-Penetrating, Guanidinium-Rich Oligophosphoesters: Effective and Versatile Molecular Transporters for Drug and Probe Delivery. J. Am. Chem. Soc. 2016, 138, 3510-3517. [CrossRef] [PubMed]

42. Pranantyo, D.; Xu, L.Q.; Kang, E.-T.; Mya, M.K.; Chan-Park, M.B. Conjugation of polyphosphoester and antimicrobial peptide for enhanced bactericidal activity and biocompatibility. Biomacromolecules 2016, 17, 4037-4044. [CrossRef] [PubMed]

43. Zhang, F.; Zhang, S.; Pollack, S.F.; Li, R.; Gonzalez, A.M.; Fan, J.; Zou, J.; Leininger, S.E.; Pavía-Sanders, A.; Johnson, R.; et al. Improving paclitaxel delivery: In vitro and in vivo characterization of PEGylated polyphosphoester-based nanocarriers. J. Am. Chem. Soc. 2015, 137, 2056-2066. [CrossRef] [PubMed]

44. Schöttler, S.; Becker, G.; Winzen, S.; Steinbach, T.; Mohr, K.; Landfester, K.; Mailänder, V.; Wurm, F.R. Protein adsorption is required for stealth effect of poly(ethylene glycol)- and poly(phosphoester)-coated nanocarriers. Nat. Nanotech. 2016, 11, 372-377. [CrossRef]

45. Becker, G.; Wurm, F.R. Breathing air as oxidant: Optimization of 2-chloro-2-oxo-1,3,2-dioxaphospholane synthesis as a precursor for phosphoryl choline derivatives and cyclic phosphate monomers. Tetrahedron 2017, 73, 3536-3540. [CrossRef] 
46. Nifant'ev, I.E.; Shlyakhtin, A.V.; Bagrov, V.V.; Minyaev, M.E.; Churakov, A.V.; Karchevsky, S.G.; Birin, K.P.; Ivchenko, P.V. Mono-BHT heteroleptic magnesium complexes: Synthesis, molecular structure and catalytic behavior in the ring-opening polymerization of cyclic esters. Dalton Trans. 2017, 46, 12132-12146. [CrossRef]

47. Mushahary, D.; Spittler, A.; Kasper, C.; Weber, V.; Charwat, V. Isolation, cultivation, and characterization of human mesenchymal stem cells. J. Quant. Cell Sci. 2018, 93, 19-31. [CrossRef]

48. Lamanna, R.; Corti, A.; Iorio, M.; Nocchi, F.; Urciuoli, P.; Lapi, S.; Scatena, F.; Franzini, M.; Vanacore, R.; Lorenzini, E.; et al. Are standard cell culture conditions adequate for human umbilical cord blood mesenchymal stem cells? Blood Transfus. 2014, 12, s375-s377. [CrossRef]

49. Baer, P.C.; Koch, B.; Hickmann, E.; Schubert, R.; Cinatl, J., Jr.; Hauser, I.A.; Geiger, H. Isolation, Characterization, Differentiation and Immunomodulatory Capacity of Mesenchymal Stromal/Stem Cells from Human Perirenal Adipose Tissue. Cells 2019, 8, 1346. [CrossRef]

C 2019 by the authors. Licensee MDPI, Basel, Switzerland. This article is an open access article distributed under the terms and conditions of the Creative Commons Attribution (CC BY) license (http://creativecommons.org/licenses/by/4.0/). 